\title{
Infeksi Saluran Kemih pada Kehamilan: Prevalensi dan Faktor-Faktor yang Memengaruhinya
}

\author{
Edy Fakhrizal*
}

\begin{abstract}
To obtain a prevalence of urinary tract infection in pregnancy andits influential risk factors. This is a cross sectional study. The subjects were all pregnant women who came to Obstetric \& Gynecology clinic of Arifin Achmad Pekanbaru - Riau Hospital, between June $1^{\text {st }}$ and October $31^{\text {st }}$ 2016. Subjects with appropriate inclusion and exclusion criteria and agreed to join this study were asked to fill out questionnaire and urinalysis test was done.The data was analyzed with Stata 12. The distribution of data was analyzed with descriptive univariate and presented in (n) and(\%). Bivariate analysis was done to see any influential risk factors to urinary tract infection in pregnancy. From recruited 74 subjects, 27 subjects $(36,5 \%)$ were with urinary tract infection and 4 subject of its $(14,8 \%)$ was asymptomatic bacteriuria. The prevalence of urinary tract infection in pregnancy in this study was $36,5 \%$ and the influential risk factors were education, occupation, total water consumpted a day, and cleaning vagina before coitus.
\end{abstract}

Key words: Urinary tract infection, pregnancy, prevalence, risk factors.

Penyakit infeksi merupakan masalah dunia yang terjadi di negara berkembang maupun negara maju. Penyakit infeksi saluran kemih merupakah masalah kesehatan terbanyak kedua yang ditemukan setelah infeksi saluran napas. Perempuan lebih beresiko menderita infeksi saluran kemih dibandingkan pada pria karena secara anatomis uretra wanita lebih pendek dari pada uretra pada pria. Perempuan saat hamil lebih beresiko lagi menderita infeksi saluran kemih karena perubahan anatomis dan fisiologis yang terjadi pada tubuhnya. Sebanyak 20\% kasus infeksi saluran kemih terjadi pada ibu hamil. ${ }^{1}$

Tidak seluruh ISK menimbulkan gejala. Penanda terjadinya ISK pada pasien bergejala (simptomatik) maupun yang tidak bergejala (asimptomatik) adalah dengan ditemukannya bakteri dalam biakan urin dalam jumlah $100.000 \mathrm{cfu} / \mathrm{ml}$ yang disebut bakteriuria. Bakteriuria pada perempuan hamil dapat berkembang menjadi

\footnotetext{
* Penulis Korespondensi :

Divisi Uroginekologi, KJF Obstetri \& Ginekologi Fakultas Kedokteran Universitas Riau- RSUD Arifin Achmad Provinsi Riau
}

pielonefritis. Prevalensi pielonephritis pada kehamilan sekitar 0.5-2\%. Bakteriuria asimptomatik pada kehamilan dapat meningkatkan resiko pielonefritis 20-30 kali lipat dibandingkan perempuan tanpa bakteriuria. Terdapat hubungan yang erat pada terjadinya persalinan prematur, preeclampsia, hipertensi, gangguan pertumbuhan janin dalam rahim / intra uterine grow restriction(IUGR) dan persalinan secara seksiosesar pada pasien hamil yang mengalami infeksi saluran kemih. Oleh karena itu infeksi saluran kemih pada kehamilan perlu mendapat perhatian yang serius. Penanganan yang cepat dapat membantu mencegah terjadinya komplikasi. ${ }^{2-4}$

Faktor-faktor risiko infeksi saluran kemihsecara umum adalah diabetes mellitus (prevalensi 8-14\%) dan inkontinensia alvi. ${ }^{5}$ Usia kehamilan yang paling berisiko mengalami bakteriuria adalah antara usia kehamilan 9 hingga 17 minggu. Delapan puluh persen perempuan dengan usia kehamilan $12-16$ minggu mengalami bakteriuria asimptomatik. ${ }^{6}$ Kondisi sosial ekonomi yang rendah, riwayat infeksi saluran kemih sebelumnya, aktif secara seksual, dan multiparitas juga berperan dalam kejadian ISK. Penelitian sebelumnya dari Sheikh et al menemukan bahwa 
riwayat gangguan urologi berhubungan dengan meningkatnya insiden infeksi saluran kemih dalam kehamilan. ${ }^{78}$ Sumber lain menyatakan ISK terjadi pada wanita yang baru saja berhubungan seksual sehari sebelumnya, atau dalam waktu 48 jam sebelumnya, meningkatkan risiko 60 kali lipat. Kebiasaan menahan berkemih hingga lebih dari 4 jam dan konsumsi air putih yang sedikit, dan kebiasaan membasuh kemaluan dari belakang ke depan menjadikan perempuan hamil rentan terhadap ISK. ${ }^{9}$

Penelitian tentang prevalensi dan faktor risiko infeksi saluran kemih pada kehamilan sangat penting untuk menentukan strategi pencegahannya, mengingat besarnya masalah yang ditimbulkan akibat ISK pada perempuan hamil.Oleh karena itu upaya identifikasi dini penyebabnya dan faktor risiko yang berperan serta kemampuan memprediksi timbulnya ISK pada permpuan hamil, menjadi sangat penting sebagai dasar pencegahan dan tatalaksana.

\section{METODE}

Penelitian ini merupakan studi potong lintang dengan satu kali pengukuran. Subjek penelitian adalah semua perempuan hamil yang datang ke Poliklinik Obstetri dan Ginekologi RSUD Arifin Achmad dengan menggunakan teknik total sampling selama periode 1 Juni - 31 Oktober 2016. Pasien primipara yang memenuhi kriteria inklusi berupa kesediaan ikut penelitian yang dibuktikan dengan menandatangani lembar informed consent, dan tidak memiliki kriteria eksklusi berupa perdarahan antepartum, pasien gagal ginjal dan gangguan ginjal lainnya, riwayat transplantasi ginjal, riwayat diabetes mellitus, riwayat konsumsi antibiotika dalam 7 hari terakhir, inkontinensia alfi, dan pasien dengan terapi imunosupresan.

Selanjutnya pada pasien dilakukan tes urin (urinalisis). Urin yang diambil adalah urin porsi tengah. Seluruh sampel diantar ke laboratorium di RSUD Arifin Achmad Pekanbaru. Pemeriksaan Dipstick dilakukan dengan mencelupkan stick ke dalam tabung bersih yang sudah diisi dengan urin sampai batas atas lembar uji selama \pm 1 detik. Hasil pemeriksaan dibaca secara visual dan dibaca pada detik 60, tidak lebih dari 120 detik. Lekosit esterase (LE) dikatakan positif bila didapatkan hasil pemeriksaan menunjukkan trace, $+1,+2$, atau +3 . Hasil pemeriksaan Nitrit dibaca secara kualitatif dengan hasil yang positif atau negatif. Pemeriksaan dipstick disebut negatif bila kedua hasil pemeriksaan memberikan hasil negatif. Pemeriksaan dipstick disebut positif bila satu atau kedua hasil pemeriksaan memberikan hasil positif.

Analisis pada penelitian ini dilakukan menggunakan program statistik komputer. Sebaran data subjek penelitian akan diolah dengan analisis univariat deskriptif dan disajikan dalam $\mathrm{n}$ dan $\%$. Untuk melihat faktor risiko (demografik dan obstetrik) yang berpengaruh terhadap kejadian infeksi saluran kemih pada kehamilan akan dilakukan analisis bivariat. Nilai $p$ yang dianggap signifikan dalam penelitian ini ditentukan sebesar 5\%. Hasil analisis akan dilaporkan dalam bentuk frekuensi dan persentase nilai $p$.

\section{HASIL}

Subjek penelitian direkrut antara bulan Juni sampai dengan Oktober 2016, sebanyak 74 perempuan hamil yang memenuhi kriteria inklusi dan eksklusi telah bersedia mengikuti penelitian ini. Dari populasi ini, 27 subjek (36,5\%) diantaranya menderita infeksi saluran kemih (ISK), sebagaimana terlihat pada bagan 1. Dari 27 perempuan hamil yang menderita infeksi saluran kemih ini, 4 subjek $(14,8 \%)$ diantaranya tidak menunjukkan gejala infeksi saluran kemih (bakteriuria asimptomatik).

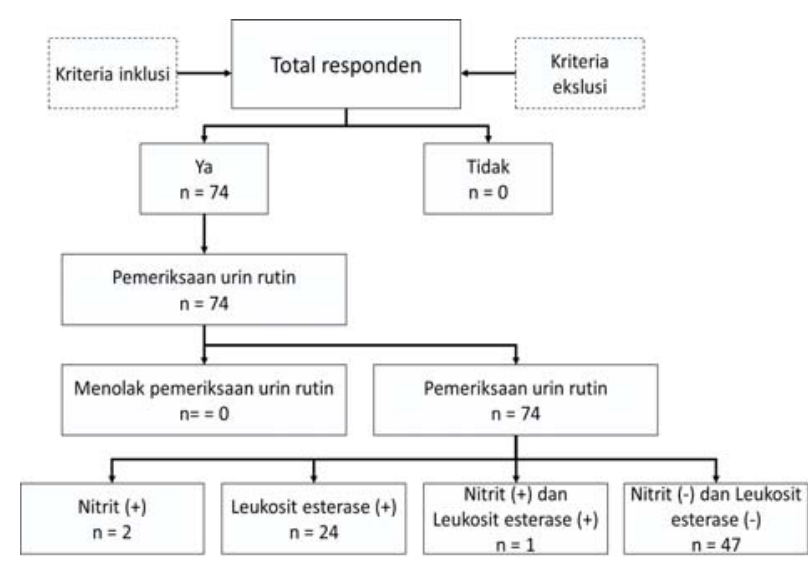

Gambar 1. Diagram alir dari studi Infeksi Saluran Kemih (ISK) 


\section{Karakterisitik Subjek Penelitian}

Sebanyak 27 subjek yang telah menyelesaikan pemeriksaan dan menunjukkan ISK memiliki karakteristik sebagaimana terlihat pada tabel 1.

Tabel 1. Karakteristik subjek penelitian

\begin{tabular}{|c|c|c|}
\hline Variabel & Kategori & Deskripsi [n(\%)] \\
\hline \multirow{3}{*}{ Umur } & $20-30$ & $17(63.3)$ \\
\hline & $31-40$ & $9(33.3$ \\
\hline & $41-50$ & $1(3.7)$ \\
\hline \multirow{5}{*}{ Pendidikan } & tidak sekolah & $0(0)$ \\
\hline & $\mathrm{SD}$ & $1(3.7)$ \\
\hline & SMP & $0(0)$ \\
\hline & SMA & $10(37.0)$ \\
\hline & Sarjana & $16(59.3)$ \\
\hline \multirow{6}{*}{ Pekerjaan } & Tidak bekerja & $8(29.6)$ \\
\hline & Guru & $0(0)$ \\
\hline & Petani & $0(0)$ \\
\hline & Tenaga kesehatan & $1(3.7)$ \\
\hline & PNS & $6(22.2)$ \\
\hline & Lainnya & $12(44.4)$ \\
\hline \multirow{2}{*}{$\begin{array}{l}\text { Penghasilan } \\
\text { (UMK Pekanbaru, 2016) }\end{array}$} & $<\operatorname{Rp} 2.146 .375$ & $10(37.0)$ \\
\hline & $>\operatorname{Rp} 2.146 .375$ & $17(63.0)$ \\
\hline \multirow{3}{*}{ Usia kehamilan } & Trimester 1 & $2(7.4)$ \\
\hline & Trimester 2 & $10(37.0)$ \\
\hline & Trimester 3 & $15(55.6)$ \\
\hline \multirow{3}{*}{ Gravida } & 1 & $10(55.6)$ \\
\hline & $2-4$ & $12(44.4)$ \\
\hline & $>4$ & $0(0)$ \\
\hline \multirow{2}{*}{ Kebiasaan menahan BAK } & Tidak & $15(55.6)$ \\
\hline & Ya & $12(44.4)$ \\
\hline \multirow{2}{*}{ Cara membasuh kemaluan } & Depan ke belakang & $22(81.5)$ \\
\hline & Belakang ke depan & $5(18.5)$ \\
\hline \multirow{3}{*}{ Jumlah minuman/hari } & $<1 \mathrm{~L}$ & $1(3.7)$ \\
\hline & $1-2 \mathrm{~L}$ & $20(74.1)$ \\
\hline & $>2 \mathrm{~L}$ & $6(22.2)$ \\
\hline \multirow{2}{*}{ Riwayat ISK sebelumnya } & Tidak & $25(92.6)$ \\
\hline & Pernah & $2(7.4)$ \\
\hline \multirow{3}{*}{ Frekuensi senggama/ bulan } & 1 kali & $2(7.4)$ \\
\hline & 2-4 kali & $22(81.5)$ \\
\hline & $5-8$ kali & $3(11.1)$ \\
\hline \multirow{2}{*}{$\begin{array}{l}\text { Membersihkan kemaluan sebelum } \\
\text { senggama }\end{array}$} & $\mathrm{Ya}$ & $14(51.9)$ \\
\hline & Tidak & $13(48.1)$ \\
\hline \multirow{2}{*}{$\begin{array}{l}\text { Membersihkan kemaluan setelah } \\
\text { senggama }\end{array}$} & $\mathrm{Ya}$ & $27(100)$ \\
\hline & Tidak & $0(0)$ \\
\hline \multirow{2}{*}{ Senggama terakhir } & $\leq 72$ jam & $5(18.5)$ \\
\hline & $>72$ jam & $22(81.5)$ \\
\hline
\end{tabular}

Uji univariat dilakukan untuk melihat karakteristik subjek dan faktor risikoyang berhubungan dengan gejala ISK pada ibu hamil. Persentase terbanyak subjek berusia 20-30 (63.3\%), pendidikan terbanyak adalah sarjana $(48.1 \%)$, terbanyak pekerjaan lainnya $(44.4 \%)$, usia kehamilan terbanyak pada trimester $3(55.6 \%)$, umumnya memiliki penghasilan lebih dari UMK Pekanbaru Rp 2.146.375 (63.0\%), umumnya yang ini adalah kehamilan pertama / gravida satu $(55,6 \%)$, 
umumnya subjek membasuh kemaluan dari arah depan ke belakang $(81,5 \%)$, dengan konsumsi air perhari terbanyak $1-2$ liter $(74,1 \%)$, umumnya subjek belum pernah menderita ISK sebelumnya $(92,6 \%)$, dengan frekuensi senggama perbulan terbanyak adalah $2-4$ kali $(81,5 \%)$, umumnya subjek membersihkan kemaluan sebelum senggama (51,9\%), semua subjek membersihkan kemaluan setelah senggama $(100 \%)$, dan senggama terakhir umumnya dilakukan lebih dari 72 jam yang lalu $(81,5 \%)$, sebagaimana terlihat pada tabel 1 .

\section{Analisis Bivariat}

Sebanyak 74 perempuan hamil yang bersedia mengikuti penelitian, 47 subjek tidak menunjukkan kelainan sedangkan 27 subjek dengan infeksi saluran kemih dalam kehamilan menjadi kelompok subjek yang dianalisis pada penelitian ini. Untuk melihat hubungan antara variabel bebas (faktor risiko) dan variabel terikat (ISK) pada penelitian ini dilakukan analisis bivariat sebagaimana terlihat pada tabel 2 .

Tabel 2. Analisis bivariat hubungan variabel faktor risiko dengan ISK dalam kehamilan

\begin{tabular}{|c|c|c|c|c|c|c|c|c|c|}
\hline \multirow{2}{*}{ Variabel } & \multirow{2}{*}{ Kategori } & \multicolumn{2}{|c|}{ ISK } & \multicolumn{2}{|c|}{ Normal } & \multirow{2}{*}{$\mathbf{P}$} & \multirow{2}{*}{ OR } & \multicolumn{2}{|c|}{ Median n (\%) } \\
\hline & & $\mathbf{N}$ & $\%$ & $\mathbf{N}$ & $\%$ & & & Min & Max \\
\hline \multirow{3}{*}{ Umur } & $20-30$ & 17 & 63,3 & 26 & 55,3 & 0.83 & & & \\
\hline & $31-40$ & 9 & 33,3 & 18 & 38,3 & & & & \\
\hline & $41-50$ & 1 & 3,7 & 3 & 6,4 & & & & \\
\hline \multirow{5}{*}{ Pendidikan } & Tidak sekolah & 0 & 0 & 0 & 0 & 0.2 & & & \\
\hline & $\mathrm{SD}$ & 1 & 3,7 & 0 & 0 & & & & \\
\hline & SMP & 0 & 0 & 1 & 2,1 & & & & \\
\hline & SMA & 10 & 37 & 9 & 19,1 & & & & \\
\hline & Sarjana & 16 & 59,3 & 37 & 78,7 & & & & \\
\hline \multirow{6}{*}{ Pekerjaan } & Tidak bekerja & 8 & 29,6 & 14 & 29,8 & 0.05 & & & \\
\hline & Guru & 0 & 0 & 4 & 8.5 & & & & \\
\hline & Petani & 0 & 0 & 0 & 0 & & & & \\
\hline & Tenaga kesehatan & 1 & 3,7 & 1 & 2,1 & & & & \\
\hline & PNS & 6 & 22,2 & 9 & 19,1 & & & & \\
\hline & Lainnya & 12 & 44,4 & 19 & 40,4 & & & & \\
\hline \multirow{2}{*}{ Penghasilan } & $<\operatorname{Rp} 2146375$ & 10 & 37 & 18 & 38,3 & 0.56 & 1.875 & 0.221 & 15.93 \\
\hline & $>\operatorname{Rp} 2146375$ & 17 & 63 & 29 & 61,7 & & & & \\
\hline \multirow{3}{*}{ Usia kehamilan } & Trimester 1 & 2 & 7,4 & 6 & 12,8 & 0.59 & 0.519 & 0.046 & 5.791 \\
\hline & Trimester 2 & 10 & 37 & 17 & 36,2 & & & & \\
\hline & Trimester 3 & 15 & 55,6 & 24 & 51,1 & & & & \\
\hline \multirow{3}{*}{ Gravida } & 1 & 10 & 55,6 & 16 & 34 & 0.65 & & & \\
\hline & $2--4$ & 12 & 44,4 & 28 & 59 & & & & \\
\hline & $>4$ & 0 & 0 & 3 & 6,4 & & & & \\
\hline \multirow{2}{*}{$\begin{array}{l}\text { Kebiasaan } \\
\text { menahan BAK }\end{array}$} & Tidak & 15 & 55,6 & 41 & 87,2 & 0.40 & 2.750 & 0.248 & 30.512 \\
\hline & $\mathrm{Ya}$ & 12 & 44,4 & 6 & 12,8 & & & & \\
\hline \multirow{2}{*}{$\begin{array}{l}\text { Cara membasuh } \\
\text { kemaluan }\end{array}$} & $\begin{array}{l}\text { Depan ke } \\
\text { belakang }\end{array}$ & 22 & 81,5 & 42 & 89,4 & 0.30 & & & \\
\hline & $\begin{array}{l}\text { Belakang ke } \\
\text { depan }\end{array}$ & 5 & 18,5 & 5 & 10,6 & & & & \\
\hline \multirow{3}{*}{$\begin{array}{l}\text { Jumlah } \\
\text { minuman/hari }\end{array}$} & $<1 \mathrm{~L}$ & 1 & 3,7 & 6 & 12,8 & 0.03 & & & \\
\hline & $1-2 \mathrm{~L}$ & 20 & 74,1 & 32 & 68,1 & & & & \\
\hline & $>2 \mathrm{~L}$ & 6 & 22 & 9 & 19,1 & & & & \\
\hline
\end{tabular}




\begin{tabular}{lllllllll}
\hline Riwayat ISK & Tidak & 25 & 92,6 & 47 & 100 & 0.54 & & \\
sebelumnya & Pernah & 2 & 7,4 & 0 & 0 & & & \\
\hline Frekuensi & 1 kali & 2 & 7,4 & 6 & 12,8 & 0.55 & & \\
senggama/bulan & $2-4$ kali & 22 & 81,5 & 36 & 76,6 & & & \\
& $5-8$ kali & 3 & 11,1 & 5 & 10,6 & & & \\
\hline Membersihkan & Ya & 14 & 51,9 & 28 & 59,6 & 0.24 & 0.256 & 0.023 \\
kemaluan sebelum & Tidak & 13 & 48,1 & 19 & 40,4 & & & \\
senggama & Ya & 27 & 100 & 46 & 97,9 & 0,67 & & \\
\hline Membersihkan & 0 & 0 & 1 & 2,1 & & & \\
kemaluan sesudah & Tidak & 5 & 18,5 & 12 & 12,5 & 0.72 & 1.583 & 0.129 \\
senggama & $\leq 72$ jam & 22 & 81,5 & 35 & 74,5 & & & 19.422 \\
\hline $\begin{array}{l}\text { Riwayat } \\
\text { senggama terakhir }\end{array}$ & $>72$ jam & & & & & & \\
\hline
\end{tabular}

Variabel dengan hasil uji chi-square pada analisis bivariat dengan nilai $p<0,25$ dianggap memiliki hubungan dengan kejadian buruk (ISK). ${ }^{10}$ Analisis bivariat didapatkan bahwa usia ibu, pendidikan, penghasilan, usia kehamilan, jumlah kehamilan, cara membasuh kemaluan, frekuensi senggama perbulan, membersihkan kemaluan setelah senggama dan riwayat ISK sebelumnya tidak memiliki hubungan dengan kejadian ISK. Adapun faktor risiko yang memiliki hubungan dengan kejadian ISK adalah pendidikan $(p 0,2)$, pekerjaan $(p 0,05)$, jumlah minuman perhari $(p$ $0,03)$, dan membersihkan kemaluan sebelum senggama $(p 0,24)$, sebagaimana terlihat pada tabel 2.

\section{PEMBAHASAN}

Pada penelitian ini didapatkan 27 subjek $(36,5 \%)$ yang menderita infeksi saluran kemih pada kehamilan. Hasil ini lebih tinggi daripada yang didapatkan oleh Lee et al yang menyebutkan bahwa seorang perempuan hamil memiliki risiko infeksi saluran kemih sebesar 2-10\%. ${ }^{11}$

Sebanyak 27 subjek yang menderita infeksi saluran kemih pada perempuan hamil ini, 4 subjek $(14,8 \%)$ diantaranya tidak menunjukkan gejala klinis infeksi saluran kemih (bakteriuria asimptomatik). Pada studi Wagenlehner et al melaporkan bahwa pada wanita hamil, $20-40 \%$ kasus merupakan bakteriuria asimptomatik. ${ }^{12}$

Untuk melihat pengaruh faktor risiko terhadap kejadian infeksi saluran kemih pada kehamilan, semua variabel dilakukan analisis bivariat. Variabel dengan hasil uji chi-square pada analisis bivariat dengan nilai $p<0,25$ dianggap memiliki hubungan dengan kejadian buruk (ISK). Hasil analisis bivariat terhadap semua faktor risiko sebagaimana disajikan pada tabel 2 menunjukkan bahwa faktor risiko yang memiliki hubungan dengan kejadian ISK adalah pendidikan $(p 0,2)$, pekerjaan $(p 0,05)$, jumlah minuman perhari $(p 0,03)$, dan membersihkan kemaluan sebelum senggama ( $p 0,24)$.

Studi mendapatkan bahwa frekuensi ISK lebih tinggi pada kelompok sosial ekonomi rendah di Arab Saudi, yang memiliki angka $14,2 \% .{ }^{8}$ Pendidikan yang rendah dan pekerjaan dengan penghasilan yang rendah mencerminkan standar hidup yang rendah. Dapat disimpulkan bahwa standar hidup yang lebih tinggi di dunia industri memiliki hubungan erat dengan rendahnya kejadian infeksi saluran kemih. ${ }^{3}$, 8,13

Minum yang banyak dianggap dapat membilas dan mendilusi urin sehingga membantu mengeradikasi bakteri dari saluran kemih. ${ }^{14}$ Stauffer et al (2004) dan Rudaitis et al (2009) pada studi mereka menunjukkan bahwa konsumsi cairan yang rendah akan meningkatkan risiko terjadinya infeksi saluran kemih pada perempuan. ${ }^{15,16}$

Faktor risiko terjadinya ISK pada kehamilan dapat juga disebabkan oleh aktifitas seksual. ${ }^{17,18}$ Senggama dapat menyebabkan trauma pada lapisan epitel saluran uretra sehingga terjadi invasi bakteri. ${ }^{3,17}$ Daerah perineum merupakan penghubung antara bakteri saluran pencernaan yang kemudian berkembang dan menyebabkan 
ISK. ${ }^{3,19}$ Membersihkan kemaluan dan perineum sebelum senggama akan sangat mengurangi koloni bakteri yang masuk dan berkembang di dalam saluran kemih.

\section{KESIMPULAN}

Prevalensi infeksi saluran kemih pada kehamilan pada penelitian ini adalah $36,5 \%$ dan $14,8 \%$ diantaranya adalah bakteriuria asimptomatik. Adapun faktor-faktor risiko yang mempengaruhinya adalah pendidikan, pekerjaan, jumlah air yang diminum perhari, dan membersihkan kemaluan sebelum senggama.

\section{DAFTAR PUSTAKA}

1. Fitz Gerald MP, Graziano S. Anatomic and functional changes of the lower urinary tract during pregnancy. Urol Clin North Am 2007; 34: 7-12.

2. Schnarr J, Smaill F. Asymptomatic bacteriuria and symptomatic urinary tract infections in pregnancy. Eur J Clin Invest 2008; 38: 50-7.

3. Himpunan Uroginekologi Indonesia. Pedoman Nasional Pelayanan Kedokteran (PNPK) Infeksi Saluran Kemih Pada Kehamilan. Jakarta; 2015. p. 1-27.

4. Lees C. Urinary tract infection (UTI). Eur J Obstet Gynecol Reprod Biol 2011; 156(2): 1316.

5. Dalal S, Nicolle L, Marrs CF, Zhang L, Harding G, Foxman B. Long-term Escherichia coli asymptomatic bacteriuria among women with diabetes mellitus. Clin infect dis 1995: 316-22.

6. Stenqvist K, Dahlen-Nilsson I, Lidin-Janson G, Lincoln K, Oden A, Rignell S et al. Bacteriuria in pregnancy. Frequency and risk of acquisition. Am J Epidemiol 1989; 129: 273-9.

7. Sheikh MA, Khan MS, Khatoon A, Arain GM. Incidence of urinary tract infection during pregnancy. East Mediterr Health J 2000; 6: 26571.

8. Haider G, Zehra N, Munir AA, Haider A. Risk factors of urinary tract infection in pregnancy. $\mathrm{J}$ Pak Med Assoc 2010; 60(3).
9. Amiri FN, Rooshan MH, Ahmady MH, Soliamani MJ. Hygiene practices and sexual activity associated with urinary tract infection in pregnant women. East Mediterr Health J 2009; 15: 104-10. .

10.Dahlan MS. Langkah-langkah membuat proposal penelitian bidang kedokteran dan kesehatan. Jakarta: Sagung Seto; 2010. 215 p.

11.Lee M, Bozzo P, Einarson A, Koren G. Urinary tract infections in pregnancy. Can Fam Physicians 2008; 54: 853-4.

12.Wagenlehner FM, Weidner W, Naber KG. An update on uncomplicated urinary tract infections in women. Current Opinion in Urology 2009; 19: 368-74. .

13. Obiogbolu $\mathrm{CH}$, Okonto IO, Anyamere CO, et al. Incidence of urinary tract infections (UTIs) among pregnant women in Akwa metropolis, Southeastern Nigeria. Sci Res Essays 2009;4: $820-4$.

14.Beetz R. Mild dehydration: a risk factor of urinary tract infection? Eur J Clin Nutr 2003; 57 Suppl 2: 552-8.

15. Stauffer CM et al. Family history and behavioral abnormalities in girls with recurrent urinary tract infections: a controlled study. J Urol 2004; 171(4): 1663-5.

16. Rudaitis $\mathrm{S}$ et al. Recurrent urinary tract infection in girls: do urodynamic, behavioral an functional abnormalities play a role? J Nephrol 2009; 22(6): 766-73.

17.McCormick T, Ashe RG, Kearney PM. Urinary tract infection in pregnancy. The Obstetrician \& Gynaecologist 2008; 10(3): 156-62.

18. Ramzan M, Bakhsh S, Salam A, Khan GM, Mustafa G. Risk factors in urinary tract infection. Gamal Journal of Medical Sciences 2004; 2(1): 1997-2067.

19. Khatun S, Nessa A, Mahmood A. Urinary tract infections in pregnancy. The Orion 1994; 4:1520. 